\title{
Above- and belowground dynamics of plant community succession following abandonment of farmland on the Loess Plateau, China
}

\author{
Guoliang Wang • Guobin Liu • Mingxiang Xu
}

Published online: 16 July 2009

(C) Springer Science + Business Media B.V. 2009

Erratum to: Plant Soil (2009) 316:227-239

DOI 10.1007/s11104-008-9773-3

1. The units for available $\mathrm{N}$ content and available $\mathrm{P}$ content in lines 23-24 of paragraph one in the Materials and methods and in Table 4 should read $\mathrm{mg} \mathrm{kg}^{-1}$

2. The vertical axis units for Fig. 2 should read $\mathrm{dm}^{2} \mathrm{~m}^{-2}$

Responsible Editor: Tibor Kalapos.

The online version of the original article can be found under doi:10.1007/s11104-008-9773-3.

G. Wang $(\bowtie)$

Institute of Soil and Water Conservation,

Northwest Sci-Tech University of Agriculture and Forestry,

Yangling, Shaanxi province 712100 ,

People's Republic of China

e-mail: glwang@nwsuaf.edu.cn

G. Liu

Institute of Soil and Water Conservation,

Chinese Academy of Sciences,

Yangling, Shaanxi province 712100 ,

People's Republic of China

e-mail: gbliu@ms.iswc.ac.cn

M. Xu

State Key Laboratory of Soil Erosion

and Dryland Farming on the Loess Plateau,

Yangling, Shaanxi province 712100 ,

People's Republic of China

e-mail: mxxu@nwsuaf.edu.cn 